\title{
An improved method for the determination of dissolved nitric oxide (NO) in seawater samples
}

\author{
H. E. Lutterbeck and H. W. Bange \\ Chemical Oceanography, Division of Marine Biogeochemistry, GEOMAR Helmholtz Centre for \\ Ocean Research Kiel, Kiel, Germany \\ Correspondence to: H. E. Lutterbeck (hlutterbeck@geomar.de)
}

Received: 13 April 2015 - Published in Ocean Sci. Discuss.: 4 June 2015

Revised: 11 November 2015 - Accepted: 12 November 2015 - Published: 27 November 2015

\begin{abstract}
Nitric oxide (NO) is a short-lived intermediate of the oceanic nitrogen cycle; however, due to its high reactivity, measurements of dissolved NO in seawater are rare. Here we present an improved method to determine NO concentrations in discrete seawater samples. The set-up of our system consisted of a chemiluminescence NO analyser connected to a stripping unit. The limit of detection for our method is 5 pmol NO in aqueous solution, which translates into $0.25 \mathrm{nmol} \mathrm{L}^{-1}$ when using a $20 \mathrm{~mL}$ seawater sample volume. Our method was applied to measure high-resolution depth profiles of dissolved NO during a cruise to the eastern tropical South Pacific Ocean. It is fast and comparably easy to handle; thus it opens the door for investigating the distribution of NO in the ocean, and it facilitates laboratory studies on NO pathways.
\end{abstract}

\section{Introduction}

Nitric oxide (NO) is a short-lived intermediate of various microbial processes of the nitrogen cycle (see e.g. Thamdrup, 2012). Molecular analysis and lab culture experiments have shown that various kinds of bacteria are able to metabolize NO, e.g. ammonium-oxidizing bacteria (Lipschultz et al., 1981), nitrite-oxidizing bacteria (Freitag and Bock, 1990), methanotrophic bacteria (Yoshinari, 1985) and denitrifying bacteria (Firestone et al., 1979). However, it is still unclear which processes are responsible for the occurrence of NO in natural environments. Although ammonium- and nitrite-oxidizing bacteria can produce NO, there is no evidence for $\mathrm{NO}$ as an intermediate during nitrification. A study which compared mathematical models with the results from a laboratory-scale waste water sludge reactor showed that denitrification indeed could be a dominating process of NO release (Kampschreur et al., 2007). The denitrification pathway has been investigated in great detail, and therefore its enzymatic NO production and the subsequent reduction of NO via the intermediate nitrous oxide $\left(\mathrm{N}_{2} \mathrm{O}\right)$ to nitrogen $\left(\mathrm{N}_{2}\right)$ are well understood (Zumft, 1997). Another process where NO is involved as an intermediate is anammox (Strous et al., 2006; Kartal et al., 2011). The latest discovery was the enzymatic dismutation of NO resulting in the microbial production of oxygen $\left(\mathrm{O}_{2}\right)$ used to oxidize methane under anaerobic conditions (Ettwig et al., 2010, 2012). Additionally, NO can be produced in the ocean surface layer by the photochemical reduction of dissolved nitrite $\left(\mathrm{NO}_{2}^{-}\right)$(Zafiriou and True, 1979; Olasehinde et al., 2010).

In summary, there are various potential microbial NO production/consumption pathways in the ocean. Unfortunately, our knowledge about the oceanic NO distribution and the major pathways of NO is very poor. There are only a few published NO concentration measurements available (Bange, 2008) because a reliable and easy-to-use method to determine dissolved NO at in situ concentrations in seawater samples is lacking.

Gaseous and dissolved NO is a very reactive and, thus, short-lived molecule because it is a free radical. Its occurrence is predominantly dependent on the presence of $\mathrm{O}_{2}$ (Lewis and Deen, 1994). Therefore, the determination of dissolved NO under in situ conditions is challenging. A summary of the existing methods for the determination of NO is given by Hetrick and Schoenfisch (2009). The published methods for measurement of dissolved NO in seawater are listed in Table 1. The detection limits range from 0.0015 
Table 1. Overview of published methods for NO detection in seawater with the respective limit of detection (LOD) for each method.

\begin{tabular}{lll}
\hline Method & LOD $\left[\mathrm{nmol} \mathrm{L}^{-1}\right]$ & Reference \\
\hline Microelectrode & 140 & Zhang et al., 2003 \\
Microelectrode & 42 & Xing et al., 2005 \\
Microelectrode & 30 & Schreiber et al., 2008 \\
Fluorometric & $0.0124^{*}$ & Olasehinde et al., 2009 \\
Chemiluminescence & 0.0015 & Ward and Zafiriou, 1988 \\
Chemiluminescence & 0.25 & This study \\
\hline
\end{tabular}

* LOD for the conversion product from the reaction of $\mathrm{NO}$ with the trapping compound

to $140 \mathrm{nmol} \mathrm{L}^{-1}$. (Please note that the fluorometric detection of NO as described by Olasehinde et al., 2009, is suitable only for formation rates of $\mathrm{NO}$ from $\mathrm{NO}_{2}^{-}$). The sensor of Schreiber et al. (2008) was developed for sediments but works in seawater samples as well. The chemiluminescence system of Zafiriou and McFarland (1980) consisted of an NO analyser connected to a stripping unit and is, thus, similar to the set-up described here. The method by Zafiriou and McFarland (1980) is the only one yet to be applied on board to measure NO depth profiles during a cruise (Ward and Zafiriou, 1988). However, the required intensive cleaning of the Niskin bottles prior to the CTD/rosette casts together with the fact that each depth was sampled with a separate cast resulted in a time-consuming and unhandy sampling procedure.

Therefore, it was the aim of this study to develop an improved (easy to handle) method for the detection of dissolved NO in discrete seawater samples at in situ concentrations in order to decipher its role in the oceanic nitrogen cycle.

\section{Material and methods}

\subsection{Instrumental set-up}

The set-up of our system consisted of a NO analyser connected via a four-way gas stream selecting valve to a stripping unit and to the gas cylinders for reference gas and carrier gas (Fig. 1).

The carrier gas $\left(\mathrm{N}_{2}\right)$ and the reference gas $(1000 \mathrm{ppb} \mathrm{NO}$ in $\mathrm{N}_{2}$ ) were connected to a two-channel mass flow controller with mixing chamber (HTK Hamburg GmbH, Hamburg, Germany) to ensure a constant gas flow rate of $1 \mathrm{~L} \mathrm{~min}^{-1}$ and to enable the calibration of the detector signal (see Sect. 2.4.1). The mass flow controller, in turn, was connected to the gas stream selecting valve. This four-way valve enabled us to switch between two modes of gas flow: mode A enabled the direct measurement of the reference gas and carrier gas, and mode B allowed detection of the gas stream after going through the stripping unit.

The sample and stripping vials were connected to the gas line by needles (diameter $1.2 \mathrm{~mm}$ ) pushed through the respective septa. Two inline filters (Whatman Solvent IFD, $0.2 \mu \mathrm{m}$, GE Healthcare UK Limited, Buckinghamshire, Eng-

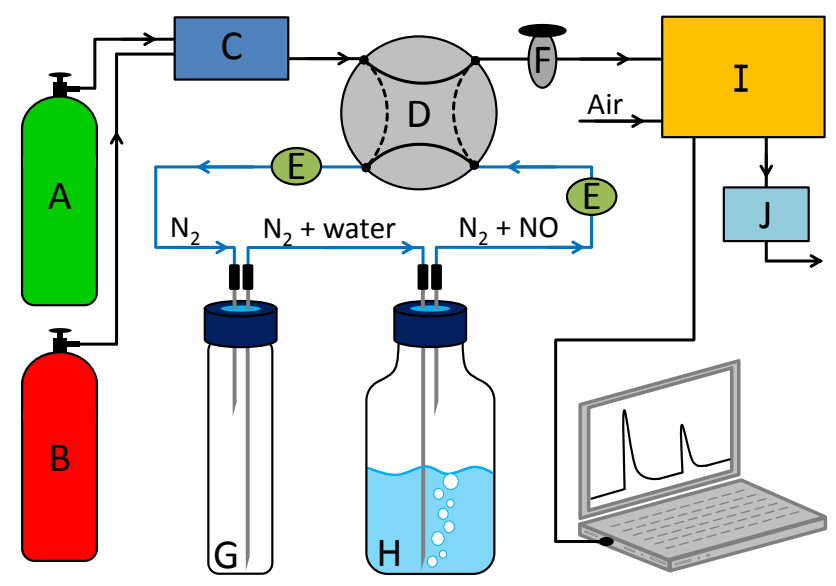

Figure 1. Schematic set-up of the developed measurement system consisting of an NO analyser connected to a stripping unit (blue lines). A: $\mathrm{N}_{2}$ gas cylinder; B: reference gas cylinder; C: mass flow controller; D: four-way valve (solid lines: mode A; dashed lines: mode B); E: inline filter; F: needle valve; G: sample vial; H: stripping vial filled with water; I: NO analyser with air supply for ozone generator; J: vacuum pump with vent.

land) were installed to remove aerosols from the gas stream. Between the four-way valve and the NO analyser a needle valve was installed to reduce pressure variations. For a detailed description of the measurement procedure see Sect. 2.2 (samples) and 2.4 (standards) below.

For detection, we used a chemiluminescence NO analyser (model 42i-TL, Thermo Fisher Scientific Inc, Waltham, MA, USA) with a detection range from 0 to $1000 \mathrm{ppb}$. In the reaction chamber of the analyser, $\mathrm{NO}$ reacts with ozone $\left(\mathrm{O}_{3}\right)$ generated by an $\mathrm{O}_{3}$ generator and produces $\mathrm{NO}_{2}$ in an excited state $\left(\mathrm{NO}_{2}^{*}\right)$. By relaxation to the ground state the $\mathrm{NO}_{2}^{*}$ emits a photon. The emitted light passes an optical filter to remove interferences from other compounds and is detected by a photomultiplier. The signal recording was done with the open-source software PuTTY 0.62 (http: //filehippo.com/de/download_putty/11216/).

\subsection{Sample handling}

Sampling took place with a commonly used conductivity temperature depth sensor, equipped with a Niskin bottle rosette (CTD/rosette) as well as with a pump CTD (pCTD) system (Strady et al., 2008) during the Meteor cruise M93 from 6 February to 11 March 2013 to the eastern tropical South Pacific off Peru (Callao, Peru, to Panama City, Panama). Seawater samples were taken bubble free in $20 \mathrm{~mL}$ brown glass vials, closed with rubber plugs and crimped with aluminium caps. Immediately after sampling all samples were stored in a cooling box $\left(\sim 6^{\circ} \mathrm{C}\right)$ until they were measured. From each water depth three to six replicates were taken. From the CTD/rosette all samples were taken as soon as possible, after the CTD was back on the ship's working 
deck, and they were analysed within $1 \mathrm{~h}$. The samples from the pCTD were taken as soon as the target depth was reached and were measured immediately within a few minutes after sampling.

For the measurement, the four-way valve was switched to mode A to enable the connection of the sample vial by the needles. In the next step the four-way valve was switched to mode $B$ to reroute the gas flow through the stripping unit. The water of the sample was pushed with the carrier gas into the stripping vial. The stripping vial had a larger volume $(50 \mathrm{~mL})$ than the sample vial to allow purging of the sample. The dissolved NO was stripped from the sample by $\mathrm{N}_{2}$ and transported with the carrier gas stream into the analyser. The sample stayed connected with the stripping unit (mode B) until the detector signal came back to the baseline. Then the fourway valve was switched to mode $\mathrm{A}$ and the next sample was connected.

\subsection{Experiments}

For sample storage experiments we took 18 samples from the pCTD at two stations from the oxygen minimum zone (OMZ) at depths between 60 and $90 \mathrm{~m}$ and stored nine of them at room temperature $\left(\sim 24^{\circ} \mathrm{C}\right)$ and nine at $\sim 6^{\circ} \mathrm{C}$ in the dark. For the time series, triplicates per temperature were measured in various time steps.

For $\mathrm{NO}_{2}^{-}$addition tests we added $20 \mu \mathrm{L}$ of a $20 \mathrm{mmol} \mathrm{L}^{-1}$ sodium nitrite $\left(\mathrm{NaNO}_{2}\right)$ aqueous solution to about 100 samples taken at different stations and depths; this corresponds to a concentration of $20 \mu \mathrm{mol} \mathrm{L}^{-1}$, in addition to the natural concentration already present in the sample. Samples were stored for different time periods, between some minutes and some hours in warm $\left(\sim 24^{\circ} \mathrm{C}\right)$ and cold $\left(\sim 6^{\circ} \mathrm{C}\right)$ environments and then measured like normal samples. Additionally we stored control samples without $\mathrm{NO}_{2}^{-}$addition under the same conditions.

\subsection{Calibration}

\subsubsection{Detector calibration}

To calibrate the detector signal, the carrier gas $\left(\mathrm{N}_{2}\right)$ was blended with the reference gas $\left(1000 \mathrm{ppb} \mathrm{NO}\right.$ in $\left.\mathrm{N}_{2}\right)$ by the mass flow controller (see above). The resulting NO mixing ratios covered the whole detection range of the $\mathrm{NO}$ analyser (0 to $1000 \mathrm{ppb}$ ).

\subsubsection{Gas standard injection}

Discrete volumes of reference gas ranging from 0.5 to $10 \mathrm{~mL}$ were injected with a gas-tight syringe (series A-2, Valco Instruments Company Inc., Houston, TX, USA) into the empty stripper. Two different reference gases with concentrations of $1000 \mathrm{ppb}$ NO and $10 \mathrm{ppm}$ NO were used.

\subsubsection{Aqueous NO standard solutions}

For preparation of aqueous NO standard solutions a $20 \mathrm{~mL}$ brown glass vial filled with $10 \mathrm{~mL}$ Milli-Q water was purged with $\mathrm{N}_{2}$ for $1 \mathrm{~h}$ at a flow rate of $100 \mathrm{~mL} \mathrm{~min}^{-1}$ and then with pure $\mathrm{NO}$ or a reference gas $\left(1 \% \mathrm{NO}\right.$ in $\left.\mathrm{N}_{2}\right)$, at a flow rate of $5 \mathrm{~mL} \mathrm{~min}^{-1}$ for $2 \mathrm{~h}$. Assuming a solubility of $1.94 \pm 0.03 \mathrm{mmol} \mathrm{L}^{-1} \mathrm{~atm}^{-1}$ at $25^{\circ} \mathrm{C}$ for $\mathrm{NO}$ (Zacharia and Deen, 2005, and references therein) the final concentrations of the solutions were $1.94 \mathrm{mmol} \mathrm{L}^{-1}$ and $19.4 \mu \mathrm{mol} \mathrm{L}^{-1}$ respectively. The standards were stored in the dark at room temperature.

For the actual measurements $20 \mathrm{~mL}$ Milli-Q water was deoxygenated with $\mathrm{N}_{2}$ for $1 \mathrm{~h}$ at a flow rate of $150 \mathrm{~mL} \mathrm{~min}^{-1}$ in a $50 \mathrm{~mL}$ vial. Then the vial was connected to the stripping unit, followed by an injection of varying volumes (in the range from 1 to $100 \mu \mathrm{L}$ ) of standard through the septum of the vial.

\subsubsection{In situ NO formation from $\mathrm{NO}_{2}^{-}$reduction}

This calibration method is based on the in situ formation of $\mathrm{NO}$ by chemical reduction of $\mathrm{NO}_{2}^{-}$with iodide in an acidic aqueous medium (Cox, 1980). The preparation of the $\mathrm{NO}_{2}^{-}$ solution started with a stock solution of $1 \mathrm{~mol} \mathrm{~L}^{-1} \mathrm{NaNO}_{2}$ in Milli-Q water and was followed by a two-step dilution series $\left(100 \mu \mathrm{L}\right.$ in $100 \mathrm{~mL}$ Milli-Q water) to get two $\mathrm{NO}_{2}^{-}$standards with concentrations of $1 \mathrm{mmol} \mathrm{L}^{-1}$ and $1 \mu \mathrm{mol} \mathrm{L}-1$. They were stored in the dark at room temperature.

The reaction solution is made of two solutions: $11 \mathrm{~mL}$ glacial acetic acid was added to $100 \mathrm{~mL}$ Milli-Q water, yielding a $10 \%$ acetic acid (with a concentration of $1.68 \mathrm{~mol} \mathrm{~L}^{-1}$; Kester et al., 1994), and $3 \mathrm{~g}$ KI was dissolved in $100 \mathrm{~mL}$ Milli-Q water to get a $3 \% w / v$ KI solution (Garside, 1982).

Prior to a measurement, $1 \mathrm{~mL}$ of the KI solution and $1.5 \mathrm{~mL} 10 \%$ acetic acid were mixed in a $50 \mathrm{~mL}$ vial and Milli-Q water was added to a final volume of $20 \mathrm{~mL}$. The vial was purged for $20 \mathrm{~min}$ with $\mathrm{N}_{2}$ (flow rate $150 \mathrm{~mL} \mathrm{~min}^{-1}$ ) to remove the $\mathrm{O}_{2}$ and was then connected to the stripping unit. Then the $\mathrm{NO}_{2}^{-}$solution was added via the septum as described above.

\subsection{Data analysis}

The recorded NO signals (i.e. peaks) were integrated manually with Origin (OriginLab, Northampton, MA, USA). With the obtained peak areas from the standard measurements a linear calibration equation was calculated to convert the peak areas of sample measurements into concentrations.

The signal-to-noise ratio $(S / N)$ was calculated by an equation of Stauffer (2008):

$S / N=2 H / h_{\mathrm{N}}$.

$H$ stands for the height of the signal and $h_{\mathrm{N}}$ is the height of the baseline noise. For the limit of detection (LOD) the 
Table 2. Overview of the limit of detection (LOD), the limit of quantification (LOQ), the standard deviation (SD) and the estimated stability time of the applied standards types.

\begin{tabular}{lllll}
\hline Standard & LOD [pmol] & LOQ [pmol] & SD [\%] & Stability time \\
\hline Aqueous NO standard solution & 5 & 20 & 25 & 10 months \\
In situ NO formation from $\mathrm{NO}_{2}^{-}$reduction & 10 & 40 & 3 & - \\
Reference gas & 15 & 30 & 10 & 1 year \\
\hline
\end{tabular}

value of $S / N$ was set to 3 , and for the limit of quantification (LOQ) a value of 10 was used. NO signals below the detection limit were set to zero in further calculations (e.g. averaging of replicates).

\section{Results and discussion}

\subsection{Method evaluation}

\subsubsection{Standard measurements}

To assess the performance of our instrumental set-up, we calculated the LOD, the LOQ and the standard deviation (SD, average from all measurements over the whole detection range) for the different gaseous and aqueous standards. The results are summarized in Table 2. Please note that the values are given as molar amounts of substance and not as concentrations in order to get volume-independent numbers and thus a better comparability between the different kinds of standards described in Sect. 2.4.2-2.4.4. Concentrations for sample measurements are discussed in Sect. 3.1.2.

For aqueous NO standards (see Sect. 2.4.3) the lowest detectable molar amount of $\mathrm{NO}$ was 5 pmol with a SD of $25 \%$. The SD is relatively high compared to the two other used standards and may be caused by the syringes used in combination with the very small injection volumes. The syringes were open at the needle end and could not be locked. Hence during the transfer from the vial containing the standard to the stripping vial the NO concentrations could be changed by external influences (e.g. contamination by diffusion through the needle), and with a smaller volume the effects get bigger. For nitrite the formation of NO occurs in the closed system, and so the transport from one vial to the other could not affect the measured concentration. The gas standards were injected with a larger volume and gas-tight syringes. We observed that the aqueous NO solutions did not change in 10 months. This indicates that the standard solutions are stable much longer than previously reported (Mesaros et al., 1997; Menon et al., 1991).

For in situ $\mathrm{NO}$ formation from $\mathrm{NO}_{2}^{-}$reduction (see Sect. 2.4.4) the LOD was 10 pmol NO and the SD $3 \%$. The detection limit is higher than for aqueous NO solutions because NO is formed in situ, which results in broader peaks with lower peak heights. We observed no decrease of the $\mathrm{NO}_{2}^{-}$concentration in the standards during our measure- ments and conclude that the $\mathrm{NO}_{2}^{-}$solutions should be stable when kept in the dark.

Discrete gas standard measurements (see Sect. 2.4.2) had a detection limit of 15 pmol NO. By cleaning the gas-tight syringes after five measurements with $100 \%$ ethanol, the SD could be decreased from 65 to $10 \%$, whereas cleaning with Milli-Q did not improve the SD. Also a cleaning of the syringe after every measurement resulted in no further decrease of the SD. We observed no influence of the injected volume between 0.5 and $10 \mathrm{~mL}$ on the detected NO. The stability of the used reference gases ( 1 year) was given by the manufacturer.

\subsubsection{Sample measurements}

With a water volume of $20 \mathrm{~mL}$ the LOD and the LOQ for dissolved NO translate into concentrations of 0.25 and $1 \mathrm{nmol} \mathrm{L}^{-1}$ respectively. By enlarging the sample volume the detection limit can be lowered. However, the peaks will get broader with larger volume; thus the detection limit will not decrease in the same amount as the sample volume is increased. We observed, for example, that by increasing the sample volume from 20 to $80 \mathrm{~mL}$ the detection limit rose to 10 pmol detectable molar amount of NO but the detectable concentration decreased to $0.125 \mathrm{nmol} \mathrm{L}^{-1}$.

\subsection{Interferences by other components}

\subsubsection{Hydrogen sulphide $\left(\mathrm{H}_{2} \mathrm{~S}\right)$}

During cruise M93 we faced a sulfidic event close to the coast of Peru. Therefore, some of the samples contained $\mathrm{H}_{2} \mathrm{~S}$, which resulted in a strong negative detector signal (Fig. 2a). A visible negative response of the $\mathrm{NO}$ analyser (i.e. stronger than the baseline noise of the instrument) was determined down to a concentration of about $80 \mathrm{nmol} \mathrm{L}^{-1} \mathrm{H}_{2} \mathrm{~S}$, but even lower $\mathrm{H}_{2} \mathrm{~S}$ concentrations could have an impact on the NO signal such as neutralization of a positive NO signal.

The reason for the negative peaks is a change of the signal from the continuous background calibration of the NO analyser itself. Parallel to the normal detection in the reaction chamber (described at the end of Sect. 2.1) the sample is mixed in a prereactor chamber with a high amount of ozone to remove the NO before the sample is led into the reaction chamber. This leads to a continuous zero calibration of the instrument. $\mathrm{H}_{2} \mathrm{~S}$ seems to affect this background sig- 

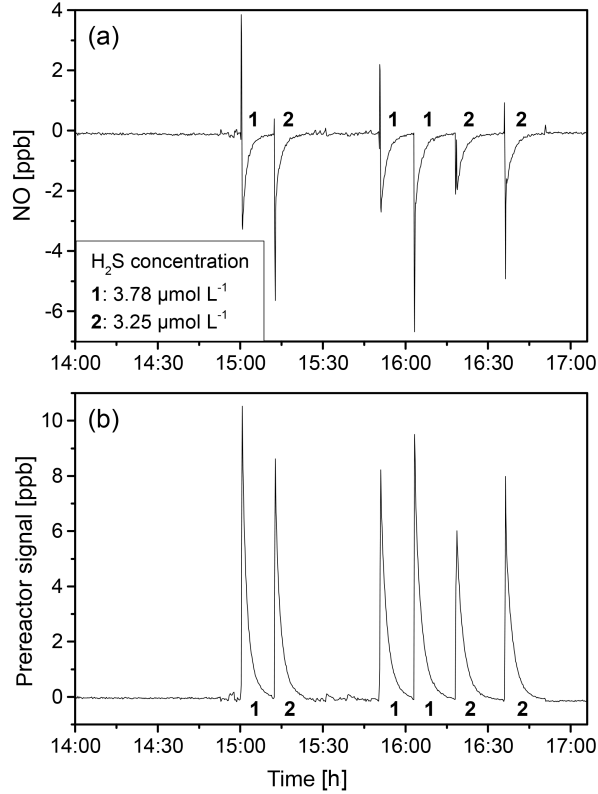

Figure 2. Detector signal for six seawater samples containing $\mathrm{H}_{2} \mathrm{~S}$. (a) Signal passing the prereactor. (b) Prereactor signal.

nal (Fig. 2b). The signal from the prereactor channel induced by $\mathrm{H}_{2} \mathrm{~S}$ is stronger than from the normal channel passing the prereactor, which leads to the negative detector signal.

Tests with addition of $\mathrm{ZnCl}_{2}$ (in order to precipitate $\mathrm{H}_{2} \mathrm{~S}$ as $\mathrm{ZnS}$ ) showed that the negative peaks of $\mathrm{H}_{2} \mathrm{~S}$ did indeed vanish, but the impact of $\mathrm{ZnCl}_{2}$ addition on the NO concentration in the sample is unknown. It might be possible that NO is removed from the sample by chemical reduction. Some preliminary lab incubation tests with Paracoccus denitrificans DSM 413 showed that $\mathrm{ZnCl}_{2}$ can also increase the NO concentration (NO concentration without $\mathrm{ZnCl}_{2}: 12 \mathrm{nmol} \mathrm{L}^{-1}$; $\mathrm{NO}$ concentration after addition of $0.5 \mathrm{~mL} 50 \% \mathrm{w} / v \mathrm{ZnCl}_{2}$ to a $30 \mathrm{~mL}$ culture: $4458 \mathrm{nmol} \mathrm{L}^{-1}$ ). A reason for that may be that NO could be involved in cell death. For example in diatoms a stress surveillance system based on NO and calcium was found which is suggested to be widespread among phytoplankton (Vardi et al., 2006, 2008; Vardi, 2008). Moreover, Hawkins et al. (2013) found a pathway including programmed cell death in a model sea anemone-dinoflagellate symbiosis. Both studies detected an increase of NO coming along with cell death. So it may be possible that the addition of $\mathrm{ZnCl}_{2}$, a common method to poison plankton, leads to an increase of $\mathrm{NO}$ in seawater samples.

\subsubsection{Nitrite $\left(\mathrm{NO}_{2}^{-}\right)$}

$\mathrm{NO}$ can photochemically be produced from dissolved $\mathrm{NO}_{2}^{-}$ (Zafiriou and True, 1979; Olasehinde et al., 2010). As $\mathrm{NO}_{2}^{-}$ can be enhanced in the water column (especially in OMZs) we performed $\mathrm{NO}_{2}^{-}$addition tests to find out if there is any light-induced production of NO caused by our sample handling.

Our experiments showed no differences in NO concentrations between samples with and without $\mathrm{NO}_{2}^{-}$addition. The addition of $1 \mathrm{~mL}$ of a $1 \mathrm{mmol} \mathrm{L}^{-1} \mathrm{NaNO}_{2}$ solution to $20 \mathrm{~mL}$ Milli-Q water resulted only in a very small NO peak. Thus we conclude that a potential in situ production of NO from $\mathrm{NO}_{2}^{-}$does not affect the measurement method described here.

\subsubsection{Organic compounds}

It is imaginable that organic compounds could also influence the detected NO concentration. A well-known fact is the release of $\mathrm{NO}$ by photolysis from nitroso compounds which have a NO group bound to an organic moiety (e.g. Ignarro et al., 1981; Adeleke and Wan, 1974). These compounds are ubiquitous in cells because they are used for the transport of NO during cell signalling (Ignarro, 1990).

To our knowledge no measurements of nitroso compounds in the ocean exist so far. Therefore, it is not possible to realistically estimate how much NO could be generated by these compounds during the sample handling. Further tests are needed to evaluate the strength of the interferences. Indeed, several methods for the detection of nitroso compounds by photolytic (e.g. Alpert et al., 1997) or chemical (e.g. Samouilov and Zweier, 1998) release of NO from nitrosylated compounds and the subsequent detection of NO by chemiluminescence exist already. It should be tested if these methods could be applied to seawater samples.

\subsection{Sample handling}

Two factors influenced the NO concentrations in the samples: the storage time (i.e. the time between sampling and the actual measurement of the sample) and the ambient $\mathrm{O}_{2}$ concentrations. This is especially important for samples from the $\mathrm{OMZ}$ where slight changes in $\mathrm{O}_{2}$ are expected to have a significant effect on dissolved NO (Lewis and Deen, 1994).

The storage experiments showed a decrease in NO concentrations over time, with a stronger decline at room temperature compared to storage at $\sim 6^{\circ} \mathrm{C}$ (Fig. 3). The decrease of the NO concentrations may be explained by the well-known common effect of bottle consumption caused by pores in the glass vials and in the rubber stoppers. However, a stronger effect on the NO concentration is probably caused by diffusion of $\mathrm{O}_{2}$ into the sample. De Brabandere et al. (2012) showed that $\mathrm{O}_{2}$ contamination can be caused by diffusion of $\mathrm{O}_{2}$ out of the rubber plugs. At room temperature the diffusion of $1 \mathrm{nmol} \mathrm{O}_{2}$ into a water sample takes only a few seconds. Compared to this, the diffusion of NO out of the sample, i.e. the bottle consumption, is negligible. Under the assumption that (i) the diffusion coefficients of $\mathrm{NO}$ and $\mathrm{O}_{2}$ are about the same (Zacharia and Deen, 2004; Goldstick and Fatt, 1970), that (ii) both compounds have the same distance 

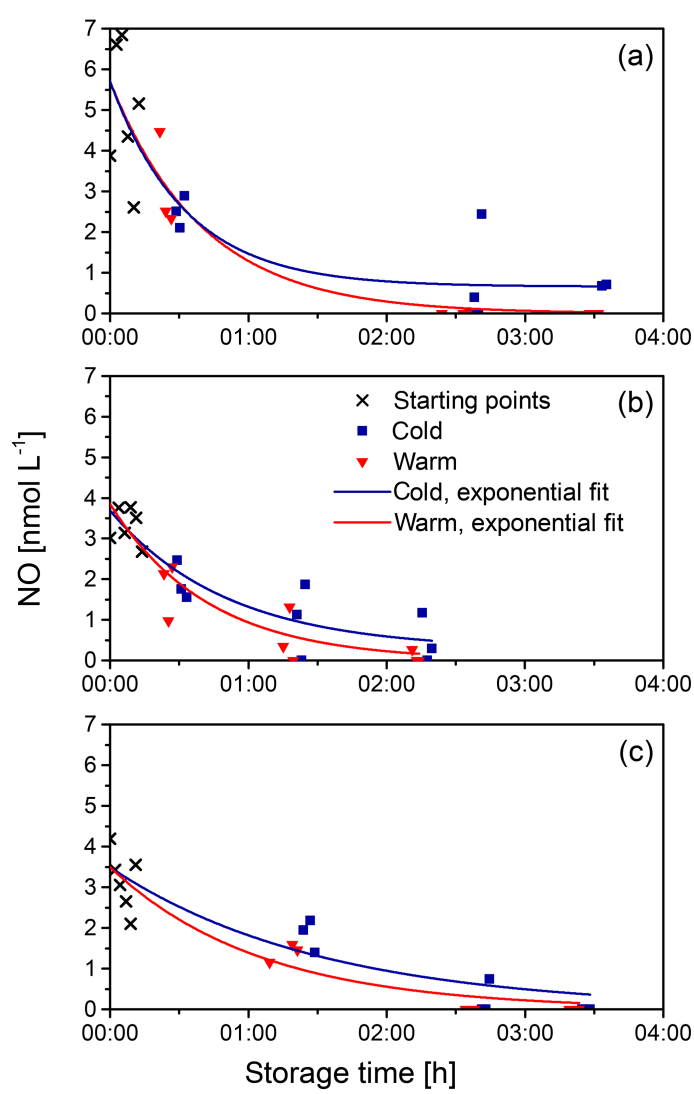

Figure 3. Degradation curves of three sample storage tests. The samples were kept in the dark at room temperature $\left(\sim 24^{\circ} \mathrm{C}\right.$, red triangles) and at $6{ }^{\circ} \mathrm{C}$ (blue squares). The measurements from the regular sampling (black crosses) were used as starting points for the curve fitting of both temperature settings. (a-b) M93 station 399-4 at $12.525^{\circ} \mathrm{S}, 77.597^{\circ} \mathrm{W}$; sampling depth: 77 and $67 \mathrm{~m}$ respectively. (c) M93 station $391-4$ at $12.668^{\circ} \mathrm{S}, 77.821^{\circ} \mathrm{W}$; sampling depth: $87 \mathrm{~m}$.

to "travel" and that (iii) the target concentration (outside the sample for $\mathrm{NO}$ and in the sample for $\mathrm{O}_{2}$ ) is zero, only the starting concentrations are important for the diffusion speed. With a starting concentration of $5 \mathrm{nmol} \mathrm{L}^{-1} \mathrm{NO}$, the diffusion of NO out of the sample is 208600 times slower than for $\mathrm{O}_{2}$ into the sample in relation to the values given by $\mathrm{De}$ Brabandere et al. (2012) for $\mathrm{O}_{2}$.

Even though $\mathrm{NO}$ is very $\mathrm{O}_{2}$ sensitive (Lewis and Deen, 1994), oxidation of $\mathrm{NO}$ by $\mathrm{O}_{2}$ alone cannot explain the decrease of $\mathrm{NO}$, because it is too slow. With concentrations of $5 \mathrm{nmol} \mathrm{L}^{-1} \mathrm{NO}$ and $1 \mu \mathrm{mol} \mathrm{L}-1 \mathrm{O}_{2}$, the half-life period of the reaction is higher than $6000 \mathrm{~h}$, and for lower concentrations it is even longer. That means that other reactions have to be responsible for the short lifetime of NO in biological systems (Kharionov et al., 1994; Ignarro et al., 1993). One reason could be that in $\mathrm{OMZ}$ waters slight changes in $\mathrm{O}_{2}$ concentrations at nanomolar levels induce strong changes of metabolic rates (Dalsgaard et al., 2014; Tiano et al., 2014;

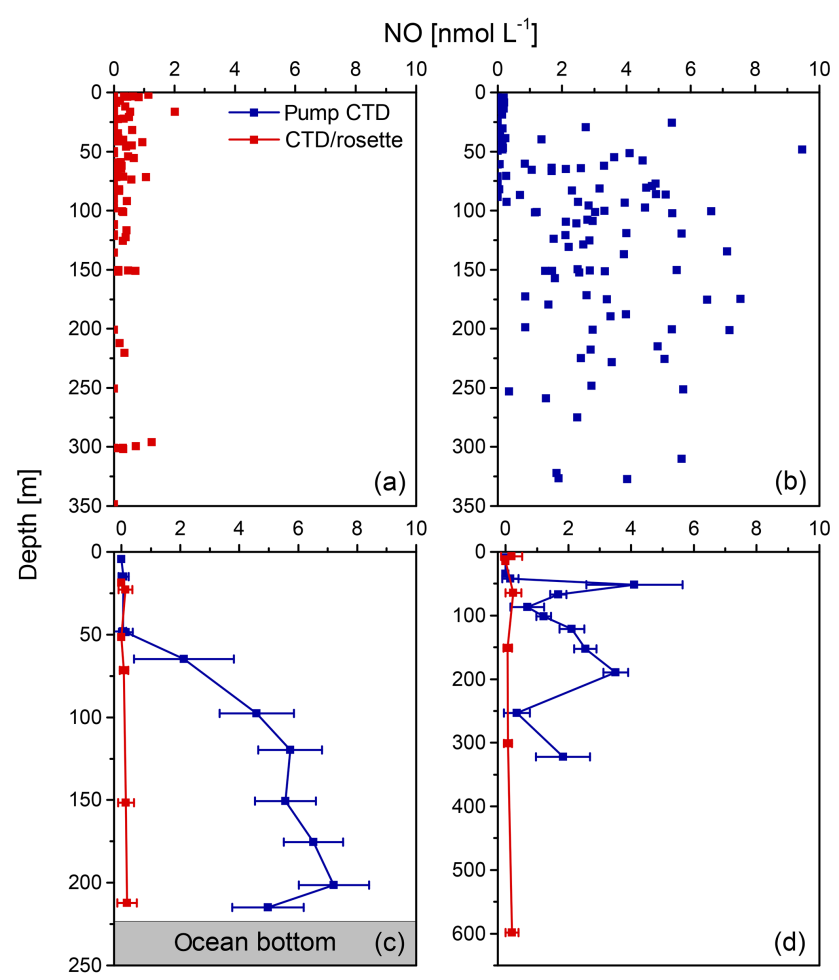

Figure 4. Comparison of the NO measurements from the CTD/rosette (red) and from the pCTD (blue). (a-b) All NO measurements during M93 between 0 and $350 \mathrm{~m}$. (c) M93 station 4116 at $12.377^{\circ} \mathrm{S}, 77.388^{\circ} \mathrm{W}$. (d) M93 station $391-4$ at $12.668^{\circ} \mathrm{S}$, $77.821^{\circ} \mathrm{W}$; the bottom depth was $1654 \mathrm{~m}$.

Kalvelage et al., 2011). Overall, it can be assumed that biological processes affected by $\mathrm{O}_{2}$ impurities are the main reason for decrease of $\mathrm{NO}$ in the sample vials.

The potential biological consumption of NO, e.g. by denitrification and anammox, in the samples from the OMZ can also explain the enhanced decrease at room temperature compared to storage at $\sim 6^{\circ} \mathrm{C}$. As the metabolic activity is higher at room temperature compared to $\sim 6^{\circ} \mathrm{C}$, more NO could be used up. Another reason for the temperature effect is that at higher temperatures the diffusion of $\mathrm{O}_{2}$ into the sample is faster and thus the effect on the NO metabolism is stronger.

The choice of the water sampling system had a large impact on the NO concentrations in the samples (Niskin bottles or pCTD). The scatter plot with our measurements from the Niskin bottles of the CTD/rosette (Fig. 4a) shows that the NO concentrations were mostly near or below the detection limit. Only a few samples showed NO concentrations of up to $2 \mathrm{nmol} \mathrm{L}^{-1}$. Contrasting to this, samples from the pCTD (Fig. 4b) showed a broad range of concentrations up to $10 \mathrm{nmol} \mathrm{L}^{-1}$. This has been confirmed by direct comparison of both CTD systems on two stations (Fig. 4c-d). No change in NO concentrations with depth was evident from CTD/rosette casts, whereas from the pCTD plausible shapes of the NO depth profiles were obtained. 
One reason for the obvious difference between the two CTD systems is most likely the time effect as found in our sample storage experiments, which might have occurred in the Niskin bottles as well. The seawater stays between $30 \mathrm{~min}$ and several hours in the Niskin bottles during the time of a CTD cast until sampling. During this time an $\mathrm{O}_{2}$ contamination of $1 \mu \mathrm{mol} \mathrm{L}^{-1}$ can be induced (Alarcón and Ulloa, 2009). This $\mathrm{O}_{2}$ entry into the bottles together with a comparably long CTD cast time may result in a strong decrease of NO even before the samples could be taken. For the pCTD system a diffusive $\mathrm{O}_{2}$ input to the water while being pumped up of only $20 \mathrm{nmol} \mathrm{L}^{-1}$ after $1 \mathrm{~h}$ of pumping has been estimated (Canfield et al., 2010), resulting in a low $\mathrm{O}_{2}$ contamination. The short residence time of the seawater in the tubing in combination with a smaller $\mathrm{O}_{2}$ contamination might have led to comparable lower NO degradation and thus in turn to higher detectable NO concentrations in the samples taken from the pCTD. However, another point should be taken into account: during the in situ pumping, cells are heavily stressed and could be disrupted, which might result in a release of intracellular NO from broken cells and/or an enhanced stressinduced NO production similar to the system found by Vardi et al. (2006).

Overall, NO samples are unstable after sampling so they have to be processed very fast. Thus, it is recommended to use a pCTD as a sampling system, and $\mathrm{O}_{2}$ contamination should be reduced to a minimum (e.g. by using deoxygenated materials). However, it may be possible that NO concentrations are rather underestimated due to sampling time and delayed until measurement.

\section{Summary}

Here we present an improved method to determine dissolved NO in discrete seawater samples. The set-up of our system consisted of a chemiluminescence NO analyser connected to a stripping unit. The lower limit of detection for our method was 5 pmol NO in aqueous solution, which corresponds to $0.25 \mathrm{nmol} \mathrm{L}{ }^{-1}$ when using a $20 \mathrm{~mL}$ seawater sample volume. Our method was applied to measure high-resolution depth profiles of dissolved NO during a cruise to the eastern tropical South Pacific Ocean. One CTD cast (including sampling) can be processed in less than $2 \mathrm{~h}$. However, for the sampling we recommend using a pCTD rather than a conventional CTD/rosette with Niskin bottles. In general, contamination by $\mathrm{O}_{2}$ diffusion into the samples should be minimized by using appropriate materials. Dissolved $\mathrm{H}_{2} \mathrm{~S}$ interferes strongly with the NO detection, whereas the in situ production of NO from dissolved $\mathrm{NO}_{2}^{-}$seems to be negligible.

The in situ formation of $\mathrm{NO}$ from $\mathrm{NO}_{2}^{-}$reduction (with iodide in acidified aqueous medium) would also allow applying our set-up for the measurements of dissolved $\mathrm{NO}_{2}^{-}$(and nitrate) in seawater samples (Garside, 1982) down to very low concentrations.

The method for the determination of dissolved NO as described here is fast and comparably easy to handle; thus it opens the door for comprehensive measurements of the distribution of oceanic NO, and it facilitates laboratory studies on NO pathways. 


\section{Appendix A}

Nitrogen $\left(\mathrm{N}_{2}, 99.999 \%\right)$, reference gases $(1000 \pm 50 \mathrm{ppb} \mathrm{NO}$ in $\mathrm{N}_{2}, 10 \pm 0.2 \mathrm{ppm} \mathrm{NO}$ in $\mathrm{N}_{2}, 1 \pm 0.02 \% \mathrm{NO}$ in $\mathrm{N}_{2}$ ), and nitric oxide (NO, $\geq 99.5 \%$ ) were purchased from Air Liquide $\mathrm{GmbH}$ (Düsseldorf, Germany). Sodium nitrite $\left(\mathrm{NaNO}_{2}\right.$, $\geq 99.0 \%$, p.a.), zinc chloride $\left(\mathrm{ZnCl}_{2}, \geq 98.0 \%\right.$, p.a. $)$ and acetic acide $(100 \%)$ were from Merck KGaA (Darmstadt, Germany). And potassium iodide (KI, $\geq 99.5 \%$, p.a.) was obtained from Carl Roth GmbH (Karlsruhe, Germany).

All tubings were from stainless steel or PTFE with a diameter of $1 / 4$ and $1 / 8 \mathrm{in}$. Valves, fittings and needles were also made of stainless steel.

Processing a measurement with our system is fast, easy and takes only a few minutes. Up to 20 measurements can be done within $1 \mathrm{~h}$.
The instrument showed a stable baseline and no drift over time for 2 years. For measurements in solution and at higher concentration ranges, it is important to include breaks and cleaning of the stripping unit between the measurements to prevent a less sensitive detection limit. The higher the NO concentrations are, the more often breaks and cleaning are needed to keep the baseline stable. The same applies for Milli-Q water and reaction solution for aqueous standard measurements. The two liquids can be reused for several measurements. The number of possible measurements done with the same liquid depends on the concentration. With higher concentrations the liquid should be replaced more often to keep the baseline constant. 
Acknowledgements. We sincerely thank the chief scientists of cruise M93, Torsten Kanzow und Gaute Lavik, as well as the crew of R/V Meteor for their support at sea. We thank D. ArévaloMartínez for his help with the sampling during the cruise. The authors thank C. Löscher for her helpful comments on an early draft of the manuscript. The financial support of the DFG-funded (Deutsche Forschungsgemeinschaft) Collaborative Research Center 754/Sonderforschungsbereich 754 "Climate-Biogeochemistry Interactions in the Tropical Ocean" (www.sfb754.de) is gratefully acknowledged.

The article processing charges for this open-access publication were covered by a Research

Centre of the Helmholtz Association.

Edited by: M. Hoppema

\section{References}

Adeleke, B. B. and Wan, J. K. S.: Further ESR evidence of the primary $\mathrm{N}-\mathrm{N}$ cleavage in the photolysis of dimethylnitrosamine: Indirect spin trapping of the primary radical NO, Mol. Photochem., 6, 329-331, 1974.

Alarcón, G. and Ulloa, O.: Cruise Report, MOOMZ-2, Departamento de Oceanografía, Universidad de Concepción, Concepción, Chile, 28 pp., 2009.

Alpert, C., Ramdev, N., George, D., and Loscalzo, J.: Detection of S-nitrosothiols and other nitric oxide derivatives by photolysischemiluminescence spectrometry, Anal. Biochem., 245, 1-7, 1997.

Bange, H. W.: Gaseous nitrogen compounds (NO, $\mathrm{N}_{2} \mathrm{O}, \mathrm{N}_{2}, \mathrm{NH}_{3}$ ) in the ocean, in: Nitrogen in the Marine Environment, 2, edited by: Capone, D. G., Bronk, D. A., Mulholland, M. R., and Carpenter, E. J., Elsevier, Amsterdam, the Netherlands, 51-94, 2008

Canfield, D. E., Stewart, F. J., Thamdrup, B., De Brabandere, L., Dalsgaard, T., Delong, E. F., Revsbech, N. P., and Ulloa, O.: A cryptic sulfur cycle in oxygen-minimum-zone waters off the Chilean coast, Science, 330, 1375-1378, 2010.

Cox, R. D.: Determination of nitrate and nitrite at the parts per billion level by chemiluminescence, Anal. Chem., 52, 332-335, 1980.

Dalsgaard, T., Stewart, F. J., Thamdrup, B., De Brabandere, L., Revsbech, N. P., Ulloa, O., Canfield, D. E., and DeLongg, E. F.: Oxygen at nanomolar levels reversibly suppresses process rates and gene expression in anammox and denitrification in the oxygen minimum zone off northern Chile, mBio, 5, e01966-14, doi:10.1128/mBio.01966-14, 2014.

De Brabandere, L., Thamdrup, B., Revsbech, N. P., and Foadi, R.: A critical assessment of the occurrence and extend of oxygen contamination during anaerobic incubations utilizing commercially available vials, J. Microbiol. Meth., 88, 147-154, 2012.

Ettwig, K. F., Butler, M. K., Le Paslier, D., Pelletier, E., Mangenot, S., Kuypers, M. M. M., Schreiber, F., Dutilh, B. E., Zedelius, J., de Beer, D., Gloerich, J., Wessels, H. J. C. T., van Alen, T., Luesken, F., Wu, M. L., van de Pas-Schoonen, K. T., Op den Camp, H. J. M., Janssen-Megens, E. M., Francoijs, K.-J., Stunnenberg, H., Weissenbach, J., Jetten, M. S. M., and Strous, M.:
Nitrite-driven anaerobic methane oxidation by oxygenic bacteria, Nature, 464, 543-548, 2010.

Ettwig, K. F., Speth, D. R., Reimann, J., Wu, M. L., Jetten, M. S. M., and Keltjens, J. T.: Bacterial oxygen production in the dark, Front. Microbiol., 3, 273, 2012.

Firestone, M. K., Firestone, R. B., and Tiedje, J. M.: Nitric oxide as an intermediate in denitrification: Evidence from nitrogen-13 isotope exchange, Biochem. Biophy. Res. Co., 91, 10-16, 1979.

Freitag, A. and Bock, E.: Energy conservation in Nitrobacter, FEMS Microbiol. Lett., 66, 157-162, 1990.

Garside, C.: A chemiluminescent technique for the determination of nanomolar concentrations of nitrate and nitrite in seawater, Mar. Chem., 11, 159-167, 1982.

Goldstick, T. K. and Fatt, I.: Diffusion of oxygen in solutions of blood proteins, Chem. Eng. Prog. S. Ser., 66, 101-113, 1970.

Hawkins, T. D., Bradley, B. J., and Davy, S. K.: Nitric oxide mediates coral bleaching through an apoptotic-like cell death pathway: evidence from a model sea anemone-dinoflagellate symbiosis, FASEB J., 12, 4790-4798, 2013.

Hetrick, E. M. and Schoenfisch, M. H.: Analytical chemistry of nitric oxide, Annu. Rev. Anal. Chem., 2, 409-433, 2009.

Ignarro, L. J.: Biosynthesis and metabolism of endothelium-derived nitric oxide, Annu. Rev. Pharmacol., 30, 535-560, 1990.

Ignarro, L. J., Lippton, H., Edwards, J. C., Baricos, W. H., Hyman, A. L., Kadowitz, P. J., and Gruetter, C. A.: Mechanism of vascular smooth muscle relaxation by organic nitrates, nitrites, nitroprusside and nitric oxide: evidence for the involvement of Snitrosothiols as active intermediates, J. Pharmacol. Exp. Ther., 218, 739-749, 1981.

Ignarro, L. J., Fukuto, J. M., Griscavage, J. M., Rogers, N. E., and Byrns, R. E.: Oxidation of nitric oxide in aqueous solution to nitrite but not nitrate: comparison with enzymatically formed nitric oxide from L-arginine, P. Natl. Acad. Sci. USA, 90, 8103-8107, 1993.

Kalvelage, T., Jensen, M. M., Contreras, S., Revsbech, N. P., Lam, P., Günter, M., LaRoche, J., Lavik, G., and Kuypers, M. M. M.: Oxygen sensitivity of anammox and coupled N-cycle processes in oxygen minimum zones, PLoS ONE, 6, e29299, doi:10.1371/journal.pone.0029299, 2011.

Kampschreur, M. J., Picioreanu, C., Tan, N., Kleerebezem, R., Jetten, M. S. M., and van Loosdrecht, M. C. M.: Unraveling the source of nitric oxide emission during nitrification, Water Environ. Res., 79, 2499-2509, 2007.

Kartal, B., Maalcke, W. J., de Almeida, N. M., Cirpus, I., Gloerich, J., Geert, W., den Camp, H., Harhangi, H. R., Janssen-Megens, E. M., Francoijs, K. J., Stunnenberg, H. G., Keltjens, J. T., Jetten, M. S. M., and Strous, M.: Molecular mechanism of anaerobic ammonium oxidation, Nature, 479, 127-130, 2011.

Kester, R. A., Wijlhuizen, A. G., Duyts, H., and Laanbroek, H. $\mathrm{J}$.: Chemiluminescence analysis of nitric oxide in small-volume samples by a modified injection method, Biol. Fert. Soils, 18, 260-262, 1994.

Kharitonov, V. G., Sundquist, A. R., and Sharma, V. S.: Kinetics of nitric oxide autoxidation in aqueous solution, J. Biol. Chem., 269, 5881-5883, 1994.

Lewis, R. S. and Deen, W. M.: Kinetics of the reaction of nitric oxide with oxygen in aqueous solutions, Chem. Res. Toxicol., 7, 568-574, 1994. 
Lipschultz, F., Zafiriou, O. C., Wofsy, S. C., McElroy, M. B., Valois, F. W., and Watson, S. W.: Production of $\mathrm{NO}$ and $\mathrm{N}_{2} \mathrm{O}$ by soil nitrifying bacteria, Nature, 294, 641-643, 1981.

Menon, N. K., Pataricza, J., Binder, T., and Bing, R. J.: Reduction of biological effluents in purge and trap micro reaction vessels and detection of endothelium-derived nitric oxide (edno) by chemiluminescence, J. Mol. Cell. Cardiol., 123, 389-393, 1991.

Mesaros, S., Grunfeld, S., Mesarosova, A., Bustin, D., and Malinski, T.: Determination of nitric oxide saturated (stock) solution by chronoamperometry on a porphyrine microelectrode, Anal. Chim. Acta, 339, 265-270, 1997.

Olasehinde, E. F., Takeda, K., and Sakugawa, H.: Development of an analytical method for nitric oxide radical determination in natural waters, Anal. Chem., 81, 6843-6850, 2009.

Olasehinde, E. F., Takeda, K., and Sakugawa, H.: Photochemical production and consumption mechanisms of nitric oxide in seawater, Environ. Sci. Technol., 44, 8403-8408, 2010.

Samouilov, A. and Zweier, J. L.: Development of chemiluminescence-based methods for specific quantitation of nitrosylated thiols, Anal. Biochem., 258, 322-330, 1998.

Schreiber, F., Polerecky, L., and de Beer, D.: Nitric Oxide Microsensor for high spatial resolution measurements in biofilms and sediments, Anal. Chem., 80, 1152-1158, 2008.

Stauffer, D.: Das Chromatogramm, in: Chromatogramme richtig integrieren und bewerten: Ein Praxishandbuch für die HPLC und GC, edited by: Kromidas, S. and Kuss, H., Wiley-VCH, Weinheim, Germany, 2008.

Strady, E., Pohl, C., Yakushev, E. V., Krüger, S., and Hennings, U.: PUMP-CTD-System for trace metal sampling with a high vertical resolution. A test in the Gotland Basin, Baltic Sea, Chemosphere, 70, 1309-1319, 2008.

Strous, M., Pelletier, E., Mangenot, S., Rattei, T., Lehner, A., Taylor, M. W., Horn, M., Daims, H., Bartol-Mavel, D., Wincker, P., Barbe, V., Fonknechten, N., Vallenet, D., Segurens, B., Schenowitz-Truong, C., Médigue, C., Collingro, A., Snel, B., Dutilh, B. E., Op den Camp, H. J. M., van der Drift, C., Cirpus, I., van de Pas-Schoonen, K. T., Harhangi, H. R., van Niftrik, L., Schmid, M., Keltjens, J., van de Vossenberg, J., Kartal, B., Meier, H., Frishman, D., Huynen, M. A., Mewes, H.-W., Weissenbach, J., Jetten, M. S. M., Wagner, M., and Le Paslier, D.: Deciphering the evolution and metabolism of an anammox bacterium from a community genome, Nature, 440, 790-794, 2006.
Thamdrup, B.: New pathways and processes in the global nitrogen cycle, Annu. Rev. Ecol. Evol. S., 43, 407-428, 2012.

Tiano, L., Garcia-Robledo, E., Dalsgaard, T., Devol, A. H., Ward, B. B., Ulloa, O., Canfield, D. E., and Revsbech N. P.: Oxygen distribution and aerobic respiration in the north and south eastern tropical Pacific oxygen minimum zones, Deep-Sea Res. Pt. I, 94, 173-183, 2014.

Vardi, A.: Cell signaling in marine diatoms, Commun. Integr. Biol., 1, 134-136, 2008.

Vardi, A., Formiggini, F., Casotti, R., De Martino, A., Ribalet, F., Miralto, A., and Bowler, C.: A stress surveillance system based on calcium and nitric oxide in marine diatoms, PLoS Biol., 4, e60, 2006.

Vardi, A., Bidle, K. D., Kwityn, C., Hirsh, D. J., Thompson, S. M., Callow, J. A., Falkowski, P., and Bowler, C.: A diatom gene regulating nitric-oxide signaling and susceptibility to diatom-derived aldehydes, Curr. Biol., 18, 895-899, 2008.

Ward, B. B. and Zafiriou, O. C.: Nitrification and nitric oxide in the oxygen minimum of the eastern tropical North Pacific, Deep-Sea Res., 35, 1127-1142, 1988.

Xing, L., Zhang, Z., Liu, C., Wu, Z., and Lin, C.: Amperometric detection of nitric oxide with microsensor in the medium of seawater and its applications, Sensors, 5, 537-545, 2005.

Yoshinari, T.: Nitrite and nitrous oxide production by Methylosinus trichosporium, Can. J. Microbiol., 31, 139-144, 1985.

Zacharia, I. G. and Deen, W. M.: Diffusivity and solubility of nitric oxide in water and saline, Ann. Biomed. Eng., 33, 214-222, 2005.

Zafiriou, O. C. and McFarland, M.: Determination of trace levels of nitric oxide in aqueous solution, Anal. Chem., 52, 1662-1667, 1980.

Zafiriou, O. C. and True, M. B.: Nitrite photolysis in seawater by sunlight, Mar. Chem., 8, 9-32, 1979.

Zhang, Z., Xing, L., Jiang, L., Wang, Y., Ren, C., and Cai, W.: The electrochemical detremination of nitric oxide in seawater media with microelectrodes, Sensors, 3, 304-313, 2003.

Zumft, W. G.: Cell biology and molecular basis of denitrification, Microbiol. Mol. Biol. R., 61, 533-616, 1997. 